\title{
Magnetic Resonance Image Denoising Using a Parallel Residual Network with Dilated and Depthwise Separable Convolutions
}

Keywords:

Posted Date: October 26th, 2020

DOl: https://doi.org/10.21203/rs.3.rs-94370/v2

License: (c) (1) This work is licensed under a Creative Commons Attribution 4.0 International License. Read Full License 


\section{Abstract}

The authors have requested that this preprint be removed from Research Square. 